\title{
Sulphur accumulation after Verticillium dahliae infection of two pepper cultivars differing in degree of resistance
}

\author{
M. Novo ${ }^{a}$, C. M. Gayoso ${ }^{a}$, F. Pomar ${ }^{\text {ad }}$, M. M. Lucas ${ }^{b}$, A. Ros Barcelóc and F. Merino ${ }^{\text {a* }}$ \\ a Departamento de Biología Animal, Biología Vegetal y Ecología, Universidad de A Coruña, La Zapateira s/n E-15071, A Coruña; \\ ${ }^{\mathrm{b}}$ Departamento de Fisiología y Ecología Vegetal, Instituto de Recursos Naturales, Centro de Ciencias Medioambientales, CSIC, Serrano \\ 115 bis E-28006 Madrid; 'Departamento de Biología Vegetal, Universidad de Murcia, E-3010 Murcia; and ${ }^{\mathrm{d} C e n t r o ~ d e ~ I n v e s t i g a c i o n e s ~}$ \\ Agrarias de Mabegondo, Apartado de Correos 10, E-15080 A Coruña, Spain
}

\begin{abstract}
Elemental sulphur levels, sulphur localization in stems, and levels of sulphate, glutathione and cysteine were studied in pepper (Capsicum annuum) cvs Yolo Wonder (higher resistance) and Luesia (lower resistance) after inoculation with Verticillium dabliae, the cause of vascular wilt. Accumulation of elemental sulphur $\left(\mathrm{S}^{0}\right)$ was first detected 10 days after inoculation in Yolo Wonder (mean $S^{0}$ level $7 \cdot 3 \mu \mathrm{g} \mathrm{g}^{-1} \mathrm{DW}$ ), and 15 days after inoculation in Luesia (mean $S^{0}$ level $3 \cdot 3 \mu \mathrm{g} \mathrm{g}^{-1}$ DW). The maximum level was reached 21 days after inoculation in Yolo Wonder (14.1 $\left.\mu \mathrm{g} \mathrm{g}^{-1} \mathrm{DW}\right)$. In control plants, elemental sulphur was not detected. SEM-EDX (scanning electron microscopy-energy dispersive X-ray microanalysis) indicated that the sulphur was not restricted to a specific location, but was dispersed throughout the vascular tissue. Sulphate levels showed a decline at the end of the experiment in inoculated plants, possibly related to the increase in sulphur levels seen in the two cultivars. The differences in sulphate levels between the two cultivars may be due to faster sulphate breakdown in cv. Yolo Wonder.
\end{abstract}

Keywords: Capsicum annuum, cysteine, glutathione, sulphate, sulphur, vascular wilt

\section{Introduction}

Verticillium dabliae is a soilborne pathogen that can infect pepper (Capsicum annuum) plants at any growth stage. The fungus produces survival structures called microsclerotia that may survive under field conditions for up 14 years even in the absence of a host. When the microsclerotia are close to the host plant root and environmental conditions are favourable, they germinate and cause infection (Bhat et al., 2003). The fungal hyphae penetrate the host through the root epidermis or wounds, crossing cortical root tissues to the xylem elements. In the xylem, the mycelium proliferates by rapid colonization of the whole vascular system (Heinz et al., 1998). The first symptom of the disease is foliar chlorosis that progresses to necrosis. Other visible symptoms include stunting, epinasty, wilting, leaf abscission and, eventually, browning of the vascular system. In general, wilting is the result of restricted water movement, due to complex interactions between toxins, enzymes and hormones (Cooper, 1984).

Verticillium wilt may be caused by V. dabliae or V. alboatrum. Verticillium wilt caused by $V$. dabliae (henceforth verticillium wilt) limits the production of a wide range

*E-mail: fuenme@udc.es

Accepted 18 April 2007 of economically important crops, including pepper, aubergine, tomato, sunflower, potato, cotton and olive tree (Pegg, 1974; Heale, 1988; Bejarano-Alcázar et al., 1996). In Mediterranean countries (Thanassoulopoulos \& Kitsos, 1972; Tsor et al., 1998; Pomar et al., 2001; Saavedra et al., 2003), verticillium wilt is a serious threat in the production of crops such as pepper, causing severe economic losses. The disease is typically managed by a combination of crop rotation, chemical methods and biological methods, but the results obtained are far from satisfactory. Pepper cultivars completely resistant to this pathogen are not known (Barriuso et al., 1989; Palloix et al., 1990; González Salán \& Bosland, 1992) although different degrees of resistance exist.

Plant resistance to pathogens often involves substances known as phytoalexins, low-molecular weight antimicrobial compounds that are synthesized by and accumulated in plants after exposure to micro-organisms (Paxton, 1981). Phytoalexin accumulation may be part of a co-ordinated defence strategy, in which any one factor alone may be unable to account for the observed resistance to a given pathogen (Mansfield, 2000). Among the phytoalexins discovered to date, perhaps the simplest is elemental sulphur, which was detected in Theobroma cacao (cocoa) stems after V. dabliae challenge (Cooper et al., 1996; Resende et al., 1996). Following the identification of sulphur as a phytoalexin, subsequent studies have investigated its 
localization in tomato plants, using the highly specific and sensitive technique of scanning electron microscopy combined with X-ray micro-analysis (SEM-EDX) (Williams et al., 2002).

Elemental sulphur formation is seen in many prokaryotes, such as photosynthetic and chemo-autotrophic sulphur bacteria and cyanobacteria (Schmidt et al., 1987; Visser et al., 1997; Reinartz et al., 1998). In eukaryotes, production of $S$ was described initially in a few fungi and algae (Ikawa et al., 1973; Pezet \& Pont, 1977; Kraus et al., 1984), with elemental free sulphur found to be an antibiotic component in the red algae Ceramiun rubrum and Erythrophyllum delesseriodides (Izak et al., 1982). Kylin et al. (1994) showed that diverse plant species, both gymnosperms and angiosperms, can produce and accumulate elemental sulphur in cell compartments such as the epicuticle. Elemental sulphur $S$ is produced by suspensions of illuminated spinach chloroplast supplied in vitro with $\mathrm{SO}_{4}^{2-}$ (Joyard et al., 1988).

As noted, Cooper et al. (1996) reported the production of elemental sulphur, as cyclo-octasulphur $\mathrm{S}_{8}$, by resistant genotypes of Theobroma cacao, in response to $V$. dabliae invasion of the xylem. Their data provide rare documentation of the cellular localization of an antimicrobial substance, and evidence for the first time of accumulation of elemental sulphur in association with a resistance response. High concentrations of sulphur were found only in scattered xylem parenchyma cells in direct contact with xylem vessels, within vessel walls and in gels (gums) occluding xylem vessels. These specific locations are of direct relevance to resistance to the xylem-invading pathogen V. dabliae. Recently, Williams et al. (2002) detected sulphur in response to $V$. dabliae challenge in a $V$. dabliaeresistant line of tomato. In the resistant line sulphur accumulation was more rapid than in the susceptible line, and the levels detected proved toxic to the fungus. More recently, sulphur accumulation has been detected in diverse families, as a component of defence against diverse pathogenic fungi and bacteria (Williams \& Cooper, 2003). In higher plants, sulphur formation seems to be widely used as an instigator of the defence response, in plants from different families including cocoa, cotton, French bean, and tomato and tobacco (Williams \& Cooper, 2003, 2004).

Sulphur, in its different oxidation states, is one of the most versatile elements in biological systems. Sulphur metabolism in plants includes its uptake from the environment, its assimilation into organic compounds, and its channelling into proteins and secondary substances (Hell, 1997). In addition, sulphur seems to form part of a complex defence response presenting physical and chemical barriers to vertical and lateral colonization by specialized pathogens (Beckman, 2000; Williams et al., 2002).

The present study investigated the possible involvement of elemental sulphur in defence responses of the pepper C. annuum to V. dabliae. Since there are no fully V. dabliaeresistant cultivars of $C$. annuum, two varieties showing different degrees of partial resistance were studied (see Pomar et al., 2004; Novo et al., 2006). Sulphur contents were analysed in plant tissues, to investigate whether sulphur accumulation may form part of the mechanism of partial resistance.

\section{Materials and methods}

\section{Fungal isolate and inoculum production}

The V. dabliae isolate UDC53Vd was collected in northwest Spain (Galicia) from infected pepper plants during a survey carried out in summer 1998 (Pomar et al., 2001). This isolate, showing high aggressiveness for pepper (Novo et al., 2006), was grown on PDA (potato dextrose agar) at room temperature for 20 days until inoculation.

\section{Plant material and growth conditions}

Seeds of the C. annuum cvs Luesia and Yolo Wonder were disinfected with sodium hypochlorite $(0.3 \%$ for $30 \mathrm{~min})$ and grown in a substrate composed of potting soil (nitrogen $300 \mathrm{mg} \mathrm{L}^{-1}, \mathrm{P}_{2} \mathrm{O}_{5} 250 \mathrm{mg} \mathrm{L}^{-1}, \mathrm{~K}_{2} \mathrm{O} 375 \mathrm{mg} \mathrm{L}^{-1}$, $\mathrm{Mg} 30 \mathrm{mg} \mathrm{L}^{-1}$, organic matter $95 \%$ ) and perlite in a 2:1 $(\mathrm{v} / \mathrm{v})$ ratio, previously sterilized at $120^{\circ} \mathrm{C}$ for $45 \mathrm{~min}$. Ten 10 -week-old plants of each cultivar were inoculated with the $V$. dabliae isolate by a modification of the method of Melouk (1992). Briefly, conidial suspensions of isolates were prepared by washing each plate with sterile water and scraping the cultures with a rubber spatula. Mycelial fragments were removed by filtration through a double layer of sterile cheesecloth, and the inoculum was adjusted to $10^{6}$ conidia $\mathrm{mL}^{-1}$. For inoculation, the roots were cut approximately $1 \mathrm{~cm}$ from the apex and suspended in the conidial suspension for $45 \mathrm{~min}$. Another group of 10 plants was treated with sterile water instead of the inoculum, as the control group. After inoculation, the plants were transplanted individually into $12-\mathrm{cm}$ diameter $400 \mathrm{~mL}$ pots with the same substrate, and placed in a greenhouse at $25^{\circ} \mathrm{C}$ with a $16 \mathrm{~h}$ light and $8 \mathrm{~h}$ dark photoperiod. Plant stems were harvested at 5, 10, 15, 20, 25 and 30 days post-inoculation (dpi) for elemental S, sulphate, and thiol analyses. All experiments were run three times.

\section{Extraction and analysis of elemental S by GC-MS}

Samples were incubated for $10 \mathrm{~min}$ in dichloromethane (HPLC grade) $\left(10 \mathrm{~mL} \mathrm{~g}^{-1}\right)$ in order to extract non-polar compounds. Elemental S was analysed and quantified by gas chromatography-mass spectroscopy (GC-MS) as ${ }^{32} \mathrm{~S}_{8}$, since this is the most abundant isotope and most common form of $S^{0}$ (Williams et al., 2002). First, a defined amount of a standard solution of ${ }^{34} \mathrm{~S}$ in dichloromethane was added to the non-polar extract. Next, the extract was filtered through Whatman 1PS filter paper into a roundbottom flask, and the dichloromethane was removed in vacuo. The residue was dissolved in $20 \mathrm{~mL}$ of hexane (HPLC grade) and passed through an $8 \mathrm{~mL}$ silica column $\left(60 \mathrm{~A}^{\circ}\right)$ for purification. The column was eluted with $20 \mathrm{~mL}$ of hexane, the effluent collected was evaporated, and the residue resuspended in $2 \mathrm{~mL}$ of dichloromethane, 
dried under a nitrogen stream, resuspended in $250 \mu \mathrm{L}$ of dichloromethane, and analysed by GC-MS.

GC-MS was done using a Thermo Finnigan Polaris Q ion trap mass spectrometer coupled to a Trace GC 2000 gas chromatograph. Compounds were separated on a DB$5 \mathrm{MS} 60 \times 0.25 \times 0.25 \mathrm{~mm}$ column with helium as carrier gas $\left(1 \mathrm{~mL} \mathrm{~min}^{-1}\right.$ constant flow). The temperature regime was $35^{\circ} \mathrm{C}$ for $2 \mathrm{~min}$, then to $200^{\circ} \mathrm{C}$ at $25^{\circ} \mathrm{C} \mathrm{m^{-1 }}$, then to $250^{\circ} \mathrm{C}$ at $5^{\circ} \mathrm{C} \mathrm{min}^{-1}$ and finally up to $320^{\circ} \mathrm{C}$ at $15^{\circ} \mathrm{C} \mathrm{min}^{-1}$. The mass spectrometer was operated in EI mode $(70 \mathrm{eV})$ running simultaneously in SCAN (50-300 amu) and SIM $\operatorname{mode}(\mathrm{m} / \mathrm{z}=256$ and 272$)$.

\section{Detection of S by SEM-EDX}

Micro-analysis was used to evaluate sulphur localization in stems of the two cultivars 29 days after inoculation with V. dahliae, as reported by Williams et al. (2002) with some modifications. Briefly, $0.5 \mathrm{~cm}$ stem sections (from the base and intermediate zone) were submerged in liquid nitrogen for $5 \mathrm{~min}$, then lyophilized for $8 \mathrm{~h}$, then placed on double-sided conductive carbon discs, and finally coated with carbon. The samples were placed on the carriers in such a way that both transverse and longitudinal sections of the stem could be observed. Prepared samples were stored in a dry place until analysis. Analysis was done in a scanning electronic microscope (JSM-6400 SEM) fitted with an EDX micro-analysis apparatus. The microanalysis was performed using the program Inca from Oxford Instruments, with an acceleration voltage of $20 \mathrm{kV}$ and a working distance of $5 \mathrm{~mm}$ from the target lens.

\section{Analysis of sulphate ions by capillary electrophoresis}

Sulphate was quantified by the method of Blake-Kalff et al. (1998) with minor modifications. Briefly, sulphate was extracted from $0 \cdot 1 \mathrm{~g}$ of lyophilized stems by incubation in $1 \mathrm{~mL}$ of deionized water at $90^{\circ} \mathrm{C}$ for $2 \mathrm{~h}$, and the extract was filtered through filter paper (no. 42 Whatman). Capillary electrophoresis was done in a capillary ion analyzer (Waters CIA) with a negative power supply $(0-30 \mathrm{kV})$, a mercury lamp for indirect UV detection to $254 \mathrm{~nm}$, and a $60 \mathrm{~cm} \times 75 \mu \mathrm{m}$ i.d. polyimide-coated fused silica capillary (Accu-Sep, Waters). The method of injection was hydrostatic for $30 \mathrm{~s}$, and the applied potential was $-15 \mathrm{kV}$. The time constant for the detector was $0 \cdot 1 \mathrm{~s}$ and the rate of data acquisition 20 points $\mathrm{s}^{-1}$. Data acquisition was done with Millennium software (Waters). The reagents used were MilliQ water (Millipore) and IonSelect High Mobility Anion Electrolyte (Waters).

\section{Analysis of cysteine and glutathione by HPLC}

For extraction of glutathione and cysteine, stem material $(100 \mathrm{mg})$ was homogenized to a fine powder and incubated for $1 \mathrm{~h}$ at room temperature in $1.5 \mathrm{~mL}$ of $0.1 \mathrm{~N} \mathrm{HCl}$ containing $0 \cdot 1 \mathrm{~g}$ of polyvinylpolypyrrolidone. Next, the samples were centrifuged at $10000 \mathrm{~g}$ for $5 \mathrm{~min}$, and aliquots of the supernatant were filtered through $0 \cdot 22 \mu \mathrm{m}$
Ultrafree MC filters (Millipore). To $100 \mu \mathrm{L}$ of filtered sample, $100 \mu \mathrm{L}$ of $1 \mathrm{M} \mathrm{pH} 9$ borate buffer was added. This buffer contained $1 \mathrm{M} \mathrm{pH} 9$ DTPA (anhydrous diethylenetriamine-penta-acetic acid) and $8.2 \mathrm{~mm}$ sodium borohydride $\left(\mathrm{NaBH}_{4}\right)$. The samples were incubated for $20 \mathrm{~min}$ at $4^{\circ} \mathrm{C}$, and then $2 \mathrm{~mL}$ of $0 \cdot 1 \mathrm{M}$ monobromobimane was added. The compounds were mixed rapidly, and left for $90 \mathrm{~min}$ in the dark at room temperature. The reaction was stopped by addition of $40 \mu \mathrm{L}$ of methysulphonic acid to $3 \%$.

Samples were analysed by high pressure liquid chromatography (HPLC) (Waters 616) on a Spherisorb S5 ODS2 column $(4.6 \times 250 \mathrm{~mm}, 5 \mu \mathrm{m}$ particle diameter $)$ with a fluorescence detector (Waters 474). The solvent gradient was 10 to $90 \%(\mathrm{v} / \mathrm{v})$ methanol in $0.25 \%(\mathrm{v} / \mathrm{v})$ acetic acid

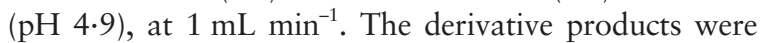
detected fluorimetrically (excitation to $380 \mathrm{~nm}$ and emission to $480 \mathrm{~nm})$.

\section{Chemicals}

DTPA, sodium borohydride and boric acid were purchased from Sigma Chemical Co, and ${ }^{32} S$ and ${ }^{34} S$ from Cambridge Isotope Laboratories. The remaining chemicals were obtained from various suppliers and were of the highest purity available.

\section{Statistical analysis}

Assays used 10 plants per treatment and were performed at least three times. The data were analysed by Student's $t$-test and one-way analysis of variance (ANOVA), at the $P=0.05$ level of significance. All analyses were performed with Statgraphics Plus $4 \cdot 0$ software for Windows.

\section{Results}

\section{Levels of elemental sulphur in inoculated stems}

GC-MS analysis indicated accumulation of elemental sulphur $\left(S^{0}\right)$ in the stems of both cvs Luesia and Yolo Wonder inoculated with $V$. dabliae, but not in control plants inoculated with sterile water (Table 1). In plants inoculated with $V$. dabliae, $\mathrm{S}^{0}$ accumulation was first detected at $15 \mathrm{dpi}$ in cv. Luesia and at $10 \mathrm{dpi}$ in Yolo Wonder. In cv. Luesia $S^{0}$ levels subsequently remained stable, whereas in Yolo Wonder, levels continued to increase until the end of the experiment $(30 \mathrm{dpi})$. At the end of the experiment, mean $S^{0}$ level in cv. Yolo Wonder (12.95 $\left.\pm 1.00 \mu \mathrm{g} \mathrm{g}^{-1}\right)$ was significantly higher than in Luesia $\left(3 \cdot 6 \pm 0 \cdot 12 \mu \mathrm{g} \mathrm{g}^{-1}\right)$.

\section{SEM-EDX localization of sulphur in inoculated stems}

Transverse and longitudinal sections of stems, cryofixed and lyophilized, were obtained at $30 \mathrm{dpi}$ from control and V. dabliae-infected plants. Sections were taken from two zones of the stem: a $0.5 \mathrm{~cm}$ section above the cotyledons (base of stem), and a $0.5 \mathrm{~cm}$ section above the fourth 
Table 1 Elemental sulphur content ( $\mu \mathrm{g}$ sulphur per $\mathrm{g}$ dry weight) in stems of the two pepper (Capsicum annuum) cultivars inoculated with Verticillium dahliae

\begin{tabular}{|c|c|c|c|c|}
\hline \multirow[b]{2}{*}{$d \mathrm{pi}^{\mathrm{a}}$} & \multicolumn{2}{|l|}{ Luesia } & \multicolumn{2}{|c|}{ Yolo Wonder } \\
\hline & Control & Inoculated & Control & Inoculated \\
\hline 5 & n.d. ${ }^{b}$ & n.d. & n.d. & n.d. \\
\hline 10 & n.d. & n.d. & n.d. & $7 \cdot 27 \pm 3.4 a$ \\
\hline 15 & n.d. & $3.26 \pm 0.12 a^{c}$ & n.d. & $10 \cdot 35 \pm 6 \cdot 7 \mathrm{ab}$ \\
\hline 20 & n.d. & $2 \cdot 16 \pm 1 \cdot 01 \mathrm{a}$ & n.d. & $14.05 \pm 5 \cdot 3 a b$ \\
\hline 30 & n.d. & $3.60 \pm 1.69 a$ & n.d. & $12.95 \pm 1.0 \mathrm{~b}$ \\
\hline
\end{tabular}

${ }^{a} \mathrm{Dpi}=$ days post inoculation

${ }^{b}$ n.d. $=$ not detectable.

'Values shown are means \pm SD of three independent experiments. Within each column, values followed by the same letter are not significantly different $(P \leq 0 \cdot 05)$.

internode. X-ray analysis detected total (not just elemental) sulphur and sulphur was detected in $V$. dabliae-infected plants of both cultivars (Fig. 1 shows cv. Yolo Wonder), but not in any specific location: rather, it was dispersed in the vascular tissue, both in vessel cell walls and in the associated parenchyma cells (Fig. 1). Scanning and transmission electron microscopy revealed colonization of vessels by $V$. dahliae hyphae. However, samples did not show vessel obstruction by tyloses or gels (Fig. 1a).

\section{Levels of sulphate in inoculated stems}

Sulphate levels in stems of both cultivars were analysed by capillary electrophoresis. In the cv. Luesia, sulphate levels were significantly higher in inoculated plants than in control plants at $5 \mathrm{dpi}$, but then declined, so that at $20 \mathrm{dpi}$ sulphate levels were higher in control plants (Fig. 2a). In cv. Yolo Wonder, sulphate levels differed little between the two treatments throughout most of the assay, but by 20 dpi levels were significantly higher in control plants, as in Luesia (Fig. 2b).

\section{Levels of glutathione and cysteine in inoculated stems}

HPLC analysis showed glutathione levels were similar in control and inoculated plants at the beginning of the experiment, independent of the cultivar (Fig. 2 c,d). At 10 dpi glutathione levels had increased in inoculated

Figure 1 Scanning electron microscopy (SEM; backscattered electron mode) and SEM-EDX (SEM-energy dispersive X-ray microanalysis) data. (a) SEM image of a transverse section of a vessel from the intermediate zone of the stem of Capsicum annuum cv. Yolo Wonder plant inoculated with Verticillium dahliae, showing fungal hyphae (f). (b) EDX spectrum of the whole area shown in (a). (c) and (d) SEM-EDX distribution maps of the area shown in (a), showing sulphur spots. Bar $=40 \mu \mathrm{mf}$.
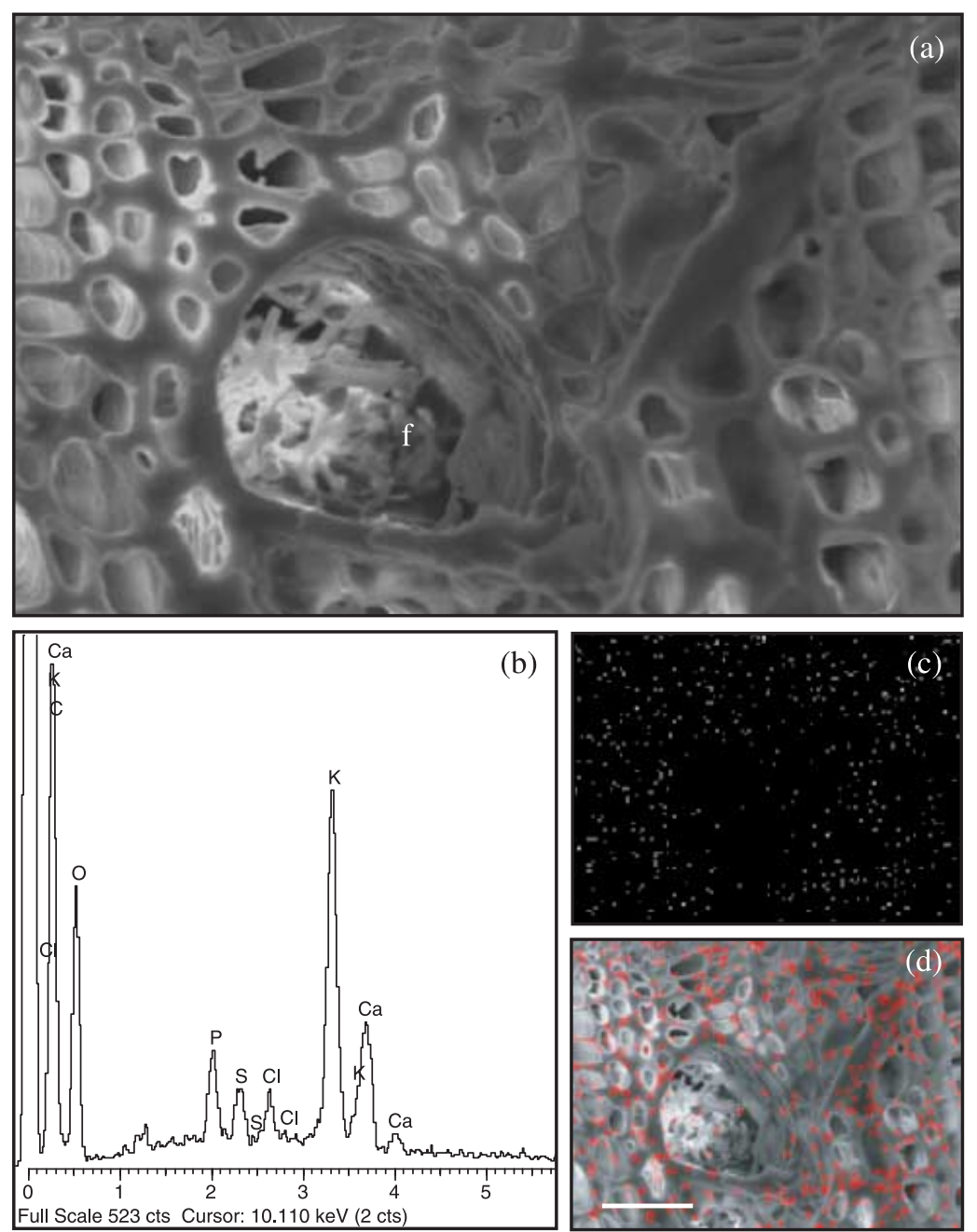


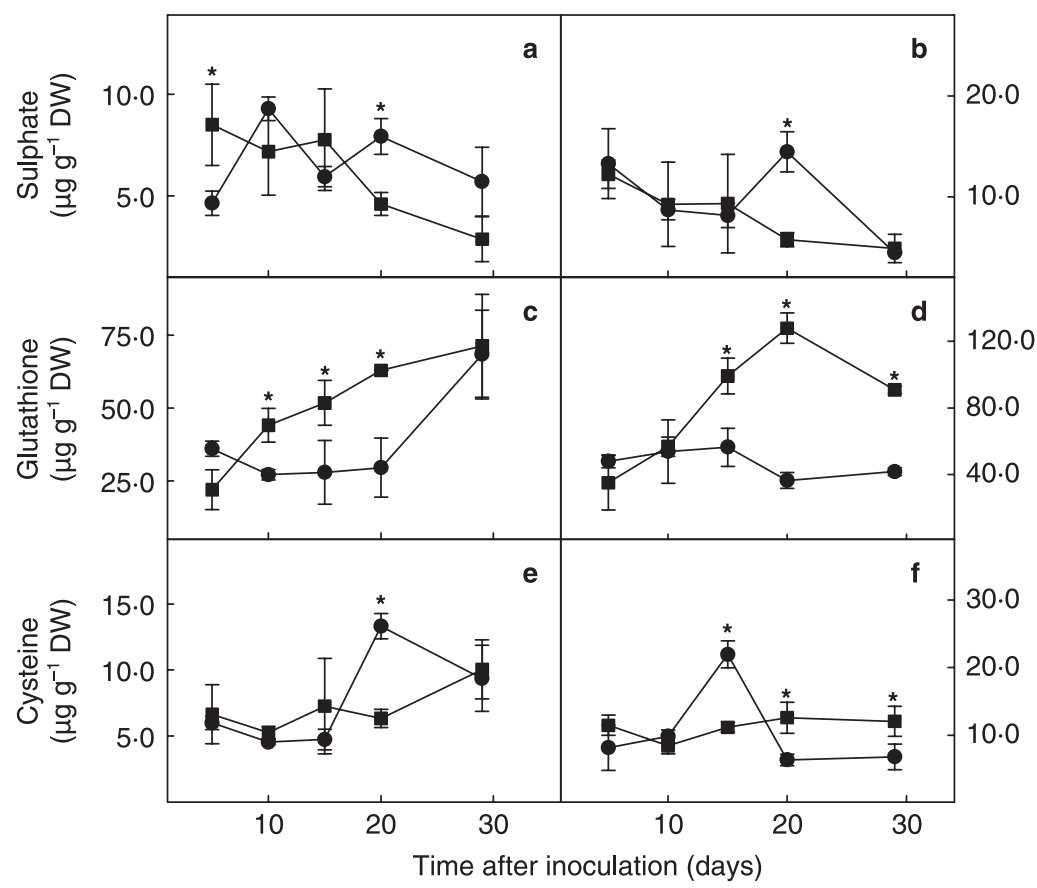

Figure 2 Time-course of sulphate $(a, b)$, glutathione $(c, d)$ and cysteine $(e, f)$ levels in stems of control (-) and Verticillium dahliaeinoculated (ם) plants of Capsicum annuum cvs Luesia (a, c, e) and Yolo Wonder (b, d, f). Results are means of three independent assays; error bars show standard deviations. Asterisks $\left({ }^{*}\right)$ indicate a significant difference with respect to that day's control $(P \leq 0 \cdot 05)$. plants with respect to control plants. In cv. Luesia, these differences were sustained until $30 \mathrm{dpi}$, when levels in control and inoculated plants were once more the same (Fig. 2c). In cv. Yolo Wonder, levels were 3-fold higher than in control plants by $20 \mathrm{dpi}$, but dropped again by 30 dpi (Fig. 2d).

Cysteine levels in V. dabliae-inoculated Yolo Wonder plants rose to approximately twice the level seen in control plants, at both 20 and 30 dpi (Fig. 2f). In contrast, in cv. Luesia cysteine levels varied over time but showed almost no differences between control and inoculated plants, throughout the experiment (Fig. 2e).

\section{Discussion}

This is the first report showing differences in sulphur accumulation patterns in response to verticillium wilt between two pepper cultivars showing differences in resistance to this disease.

Although pepper cultivars fully resistant to Verticillium dabliae are not known, some studies have indicated that cvs Luesia and Podarok have higher resistance to this pathogen than other cultivars (Barriuso et al., 1989; Palloix et al., 1990). However, in recent studies of the maintenance of leaf photosynthetic integrity in 15-day-old plants cvs Luesia, Yolo Wonder and Padrón (Pomar et al., 2004), Yolo Wonder and Padrón proved to be more resistant to $V$. dabliae than Luesia. In a subsequent study of 10 -week-old Yolo Wonder and Luesia plants, dry weight analyses showed the former to be the more resistant cultivar (Novo et al., 2006), in agreement with Pomar et al. (2004).

In the present study, the accumulation of elemental $S$ in pepper plants inoculated with V. dabliae, as quantified by the method of Resende et al. (1996) and Williams et al.
(2002), was faster and reached higher levels in the more resistant cultivar (Yolo Wonder) than in the less resistant cultivar (Luesia) (Table 1). These accumulation patterns seem to be in direct relation to the decrease in sulphate levels observed in both cultivars at the end of the assay (Fig. 2a,b). The difference in sulphate levels between the two cultivars may be due to faster breakdown of the sulphate in Yolo Wonder. In this cultivar, elemental sulphur was detected earlier, and its accumulation in the xylem was paralleled by a more marked decline in sulphate levels (Fig. 2b). Sulphate is the principal source for elemental S in plants: the sulphate is reduced to sulphide in several steps, mainly in chloroplasts (Joyard et al., 1988), and the sulphide is then incorporated into cysteine, whose formation is practically the only point of entry of reduced sulphur into organic compounds in plants. The cysteine is partially converted to methionine or glutathione. This reduced $S$ pool acts as a storage and transport form. Elemental S can be produced by the degradation of either glutathione or cysteine, giving sulphide that can be oxidized to form elemental $\mathrm{S}$ in a nonenzymatic reaction (Steudel et al., 1990). In the present study, glutathione levels increased in plant stems throughout the infection process, the increase being more marked in cv. Yolo Wonder than in Luesia. These increases could be related to transport of glutathione via the vascular tissues to the leaves, where glutathione reduction takes place. Glutathione protects the cytosol and other cell compartments against reactive oxygen species, which accumulate in response to biotic stress (Kömives et al., 1998; De Gara et al., 2003). In addition, the decrease in glutathione level seen in cv. Yolo Wonder at $30 \mathrm{dpi}$ may be related to the high levels of elemental sulphur detected at this time. Cysteine was detected at higher levels in this cultivar, in which it possibly 
acted as a source of elemental sulphur (also detected at higher levels in this cultivar).

As already noted, elemental $\mathrm{S}$ was implicated in plant defences against verticillium wilt following the discovery of $S$ accumulation in resistant lines of cocoa and tomato, in quantities sufficient in time and space to inhibit V. dabliae development (Cooper et al., 1996; Resende et al., 1996; Williams et al., 2002). Recently, Williams \& Cooper (2003) reported that sulphur is not only produced in diverse plant families, but also in response to diverse fungi and pathogenic bacteria. The patterns of accumulation of this element in tomato and other crop plants, including cotton, tobacco and French bean, are similar to those of organic phytoalexins, with faster accumulation and higher levels in resistant genotypes. However, although some susceptible cultivars show minimal sulphur accumulation, others show end-of-assay sulphur levels similar to those of resistant cultivars (Williams \& Cooper, 2003). In the present study, both pepper cultivars accumulated sulphur in stems in response to V. dabliae inoculation, this accumulation being faster and reaching higher levels in Yolo Wonder than in Luesia. Notably, the mean S level detected in stems of $\mathrm{cv}$. Yolo Wonder at $15 \mathrm{dpi}$ was higher than the values reported to be required (Williams et al., 2002) for inhibition of $V$. dabliae spore germination and hyphal growth. SEM-EDX of $V$. dabliae-infected pepper plants indicated that sulphur was dispersed throughout the vascular system, in vessel cell walls and in parenchyma cells. However, the rapid and widespread sulphur accumulation seen in Yolo Wonder, and to lesser extent in Luesia, evidently did not confer full resistance, since widespread hyphal colonization was observed. Furthermore, transmission electron microscopy did not detect xylem vessel occlusion by tyloses or gels, as commonly seen in resistant lines.

The increases in elemental sulphur levels seen in cvs Yolo Wonder and Luesia after inoculation with V. dabliae are similar to the previously reported increases in phenolic compounds in these cultivars after V. dabliae inoculation (Pomar et al., 2004). Inoculation with $V$. dabliae also increases lignin contents in stems, possibly contributing to restrict the growth of the fungal hyphae in the xylem (Pomar et al., 2004). In pepper plants, all these defensive mechanisms may work together with sulphur in a coordinated manner to control infection by $V$. dabliae. These results suggest that sulphur - though clearly not conferring full resistance - may form part of a multi-faceted response that creates physical and chemical barriers to lateral and vertical colonization by pathogens (Bell \& Mace, 1981; Cooper, 2000). The various defence mechanisms that can be activated during the response to an infection are not all equally effective for preventing colonization, but in combination they may protect against a wide range of pathogens (Dixon, 2001; Mansfield, 2000).

\section{Acknowledgements}

This work was supported by grants from the CICYT (AGF99-031), INIA (RTA04-065-C2) and Xunta de
Galicia (PGIDIT03RAG10301PR). The technical assistance of Silvia Saavedra, Belén López and Gerardo Fernández is gratefully acknowledged. Marta Novo was supported by a fellowship from the Universidad de A Coruña.

\section{References}

Barriuso J, Palazón C, Gil Ortega R, Delgado I, 1989. Characterization of Verticillium dabliae Kleb. isolates on a set of Capsicum spp. genotypes. Capsicum Newsletter 11, 37-8.

Beckman CH, 2000. Phenolic-storing cells: keys to programmed cell death and periderm formation in wilt disease resistance and in general defence responses in plants? Physiological and Molecular Plant Patholology 57, 101-10.

Bejarano-Alcázar J, Blanco-López MA, Melero-Vara JM, Jiménez-Díaz RM, 1996. Etiology, importance and distribution of Verticillium wilt of cotton in southern Spain. Plant Disease 80, 1233-8.

Bell AA, Mace ME, 1981. Biochemistry and physiology of resistance. In: Mace ME, Bell AA, Beckman CH, eds. Fungal Wilt Diseases of Plants. New York, USA: Academic Press, 431-86.

Bhat RG, Koike ST, Smith RF, Subbarao KW, Wu BM, 2003. Characterization of Verticillium dabliae isolates and wilt epidemics of pepper. Plant Disease 87, 789-97.

Blake-Kalff MMA, Harrison KR, Hakesford MJ, Zhao FJ, McGrath SP, 1998. Distribution of sulphur within oilseed rape leaves in response to sulphur deficiency during vegetative growth. Plant Physiology 118, 1337-44.

Cooper RM, 1984. The role of cell wall degrading enzymes in infection and damage. In: Wood RKS, Jellis GJ, eds. Plant Disease: Infection, Damage and Loss. Oxford, UK: Blackwell, 13-27.

Cooper RM, 2000. Verticillium - host interactions: past achievements and future molecular prospects: an overview. In: Tjamos E, Rowe R, Heale J, Fravel D eds. Advances in Verticillium Research and Disease Management. St Paul, MN, USA: APS Press, 144-50.

Cooper RM, Resende MLV, Flood J, Rowan MG, Beale MH, Potter U, 1996. Detection and cellular localization of elemental sulphur in disease resistant genotypes of Theobroma cacao. Nature 379, 159-62.

De Gara L, de Pinto MC, Tommasi F, 2003. The antioxidant systems vis à vis reactive oxygen species during plantpathogen interaction. Plant Physiology and Biochemistry 41, 865-70.

Dixon RA, 2001. Natural products and plant disease resistance. Nature 411, 843-7.

González-Salán MM, Bosland PW, 1992. Sources of resistance to Verticillium wilt in Capsicum. Euphytica 59, 49-53.

Heale JB, 1988. Verticillium spp., the cause of vascular wilts in many species. In: Andrews JH, Tommerup IC, eds. Advances in Plant Pathology, vol. 6, London, UK: Academic Press Inc., 291-312.

Heinz R, Lee SW, Saparno A, Nazar RN, Robb J, 1998. Cyclical systemic colonization in Verticillium-infected tomato. Physiological and Molecular Plant Pathology 52, 385-96.

Hell R, 1997. Molecular physiology of plant sulphur metabolism. Planta 202, 138-48. 
Ikawa M, Thomas TV Jr, Bukley LJ, Uebel JJ, 1973. Sulphur and the toxicity of the red alga Ceramium rubrum to Bacillus subtilis. Journal of Phycology 9, 302-4.

Izak RR, Stierle DB, Sims JJ, 1982. Sulphur and $\mathrm{N}$-methylformamide from the marine red alga Erythrophyllum delesserioides. Phytochemistry 21, 229.

Joyard J, Fores E, Blée E, Douce R, 1988. Characterization of elemental sulfur in isolated intact spinach chloroplasts. Plant Physiology 88, 961-4.

Kömives T, Gullner G, Király Z, 1998. Role of glutathione and glutathione-related enzymes in response of plants to environmental stress. Annals of the New York Academic of Sciences 851, 251-8.

Kraus F, Schäfer W, Schmidt A, 1984. Formation of elemental sulphur by Chlorella fusca during growth on L-cysteine ethylester. Plant Physiology 74, 176-82.

Kylin H, Atuma S, Hovander L, Jensen S, 1994. Elemental sulphur $\left(\mathrm{S}_{8}\right)$ in higher plants - biogenic or anthropogenic origin? Experientia 50, 80-5.

Mansfield JW, 2000. Antimicrobial compounds and resistance. In: Slusarenko AJ, Fraser RSS, van Loon LC, eds. Mechanisms of Resistance to Plant Diseases. Dordrecht, Netherlands: Kluwer Academic Publishers, 325-70.

Melouk HA, 1992. Verticillium. In: Singleton LL, Mihail JD, Rush CM, eds. Methods for Research on Soilborne Phytopathogenic Fungi. St Paul, MN, USA: APS Press. 175-8.

Novo M, Pomar F, Gayoso C, Merino F, 2006. Cellulase activity in isolates of Verticillium dabliae differing in aggressiveness. Plant Disease 90, 155-60.

Palloix A, Pochard E, Phaly P, Daubèze AM, 1990. Recurrent selection for resistance to Verticillium dabliae in pepper. Euphytica 47, 79-89.

Paxton JD, 1981. Phytoalexins - a working redefinition. Phytopathologishe Zeitschrift 101, 106-9.

Pegg GF, 1974. Verticillium diseases. Review of Plant Pathology 10, 56-8.

Pezet R, Pont V, 1977. Elemental sulfur: accumulation in different species of fungi. Science 196, 428-9.

Pomar F, Bernal MA, Collar J et al., 2001. A survey of "Tristeza" of pepper in Galicia and the fungal pathogens causing the disease. Capsicum Newsletter 20, 90-3.
Pomar F, Novo M, Bernal MA, Merino F, Ros Barceló A, 2004. Changes in stem lignins (monomer composition and crosslinking) and peroxidase are related with the maintenance of leaf photosynthetic integrity during verticillium wilt in Capsicum annuum. New Phytologist 163, 111-23.

Reinartz M, Tschäpe J, Brüser T, Trüper HG, Dahl C, 1998. Sulfide oxidation in the phototrophic sulfur bacterium Chromatium vinosum. Archives of Microbiology 170, 59-68.

Resende MLV, Flood J, Ramsden JD, Rowan MG, Beale MH, Cooper RM, 1996. Novel phytoalexins including elemental sulphur in the resistance of cocoa (Theobroma cacao L.) to Verticillium wilt (Verticillium dabliae Kleb.). Physiological and Molecular Plant Patholology 48, 347-59.

Saavedra A, Díaz J, Merino F, 2003. Virulence of different isolates causing Verticillium wilt of pepper in the Padrón region. Spanish Journal of Agricultural Research 1, 53-7.

Schmidt TM, Arieli B, Cohen Y, Padan E, Strohl WR, 1987. Sulfur metabolism in Beggiatoa alba. Journal of Bacteriology 169, 5466-72.

Steudel R, Holdt G, Visscher PT, van Gemerden H, 1990. Search for polythionates in cultures of Chromatium vinosum after sulfide incubation. Archives of Microbiology 153, 432-7.

Thanassoulopoulos CC, Kitsos GT, 1972. Verticillium wilt in Greece. Plant Disease Report 56, 264-7.

Tsor L, Erlich O, Amitai S, Hazanovsky M, 1998. Verticillium wilt of paprika caused by a highly virulent isolate of Verticillium dahliae. Plant Disease 82, 437-9.

Visser JM, Robertson LA, Van Verseveld HW, Gijs Kuenen J, 1997. Sulfur production by obligately chemolithoautotrophic Thiobacillus species. Applied and Environmental Microbiology 63, 2300-5.

Williams JS, Cooper RM, 2003. Elemental sulphur is produced by diverse plant families as a component of defence against fungal and bacterial pathogens. Physiological and Molecular Plant Pathology 63, 3-16.

Williams JS, Cooper RM, 2004. The oldest fungicide and newest phytoalexin - a reappraisal of the fungitoxicity of elemental sulphur. Plant Pathology 53, 263-79.

Williams JS, Hall SA, Hawkesford MJ, Beale MH, Cooper RM 2002. Elemental sulfur and thiol accumulation in tomato and defense against a fungal vascular pathogen. Plant Physiology $128,150-9$. 